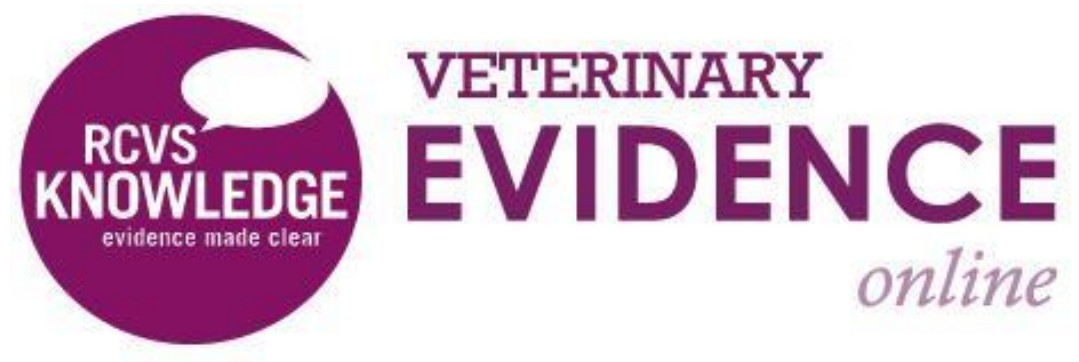

\title{
Which Sternotomy Closure Method (Orthopaedic Wire or Suture) Is Recommended in Large Breed Dogs Undergoing a Median Sternotomy?
}

A Knowledge Summary by

Charlotte Howes BVSc PGCert PGDip MRCVS ${ }^{1 *}$

Guillaume Chanoit DEDV MSc PhD DipECVS DipACVS MRCVS ${ }^{1}$

${ }^{1}$ University of Bristol, Senate House, Tyndall Ave, Bristol BS8 1TH
${ }^{*}$ Corresponding Author (h8067.2008@my.bristol.ac.uk)

ISSN: 2396-9776

Published: 14 May 2018

in: Vol 3, Issue 2

DOI: http://dx.doi.org/10.18849/ve.v3i2.159

Reviewed by: Gillian Monsell (MA, VetMB, PhD, MRCVS) and Bruce Smith (BVSc MS FANZCVS DACVS) 


\title{
KNOWLEDGE SUMMARY
}

\author{
PICO question \\ Which sternotomy closure method (orthopaedic wire or suture) is recommended in large breed dogs \\ undergoing a median sternotomy? \\ Clinical bottom line \\ The literature search revealed no clinical studies on large breed dogs comparing the clinical outcomes following \\ either orthopaedic wire or suture sternotomy closure methods. Post-mortem studies on large breed dogs \\ suggest that sutures are as suitable as orthopaedic wires for sternal closure with regards to their biomechanical \\ properties. There is insufficient clinical evidence to make a recommendation that sutures be used in large \\ breeds of dog.
}

\section{Clinical Scenario}

A 5 -year-old, male neutered Labrador, weighing $27 \mathrm{~kg}$ presents with a spontaneous pneumothorax. Following initial stabilisation and advanced imaging there is a high suspicion of pulmonary bullae. A median sternotomy is performed to examine both sides of the thorax. At surgery, a ruptured bulla is identified and a partial lung lobectomy is performed. On closure of the median sternotomy, the surgeon must decide on the best method of closure based on the evidence available.

\section{Summary of the evidence}

\begin{tabular}{|c|c|}
\hline \multicolumn{2}{|l|}{ Pelsue (2002) } \\
\hline Population: & $\begin{array}{l}\text { Research dogs with a mean weight of } 29 \pm 3 \mathrm{~kg} \text {, undergoing a median } \\
\text { sternotomy }\end{array}$ \\
\hline Sample size: & 20 \\
\hline Intervention details: & $\begin{array}{l}\text { Prior to surgery all dogs had a pre-anaesthetic complete blood count, } \\
\text { serum biochemistry and heartworm serology. Baseline heart and } \\
\text { respiratory rates and sternal pain threshold measurements were } \\
\text { obtained daily for one week prior to surgery. } \\
\text { A median sternotomy was performed using a sagittal saw. The sternum } \\
\text { was halved from the second sternebra through the xiphoid (which was } \\
\text { cut), leaving only the manubrium intact. As part of the concurrent } \\
\text { research, dogs underwent coronary arterial bypass grafting. } \\
\text { The dogs were randomised into one of the two following treatment } \\
\text { groups for median sternotomy closure: }\end{array}$ \\
\hline
\end{tabular}




\begin{tabular}{|c|c|}
\hline & $\begin{array}{l}\text { 1. Sternotomy closure using an overlapping figure-of-eight pattern } \\
\text { and no. } 2 \text { polybutester suture (10 dogs) } \\
\text { 2. Sternotomy closure using an overlapping figure-of-eight pattern } \\
\text { and } 20 \mathrm{G} \text { orthopaedic wire ( } 10 \text { dogs) } \\
\text { At day } 7 \text { post-operatively, six dogs were euthanised (three from each } \\
\text { group) and gross assessment of sternal stability was performed. } \\
\text { At day } 28 \text { post-operatively, the remaining fourteen dogs were } \\
\text { euthanised ( } 7 \text { from each group) and the sterna were split transversely } \\
\text { between the } 5^{\text {th }} \text { and } 6^{\text {th }} \text { sternebrae. The cranial portions were } \\
\text { radiographed and caudal portions were fixed for histopathology. }\end{array}$ \\
\hline Study design: & Randomised controlled trial \\
\hline Outcome studied: & $\begin{array}{l}\text { - Duration of median sternotomy closure } \\
\text { - Pain assessments at 1, 2, } 4 \text { and } 12 \text { hours post-operatively by a } \\
\text { system observer, using a multiple-category numerical rating } \\
\text { - Pain threshold measurements were obtained using a spring } \\
\text { action load device. Maximum tolerable force was recorded as } \\
\text { the pressure applied to the mid sternum that resulted in a } \\
\text { negative patient reaction or when a maximum force of } 50 \\
\text { newtons was obtained. } \\
\text { - Wound healing complications } \\
\text { - Gross sternal stability at } 7 \text { days deemed unstable if }>2 \mathrm{~cm} \text { of } \\
\text { dorsoventral displacement was manually obtained } \\
\text { Radiographic and histopathologic evidence of osteolysis and } \\
\text { fracture healing at } 28 \text { days }\end{array}$ \\
\hline $\begin{array}{l}\text { Main findings: } \\
\text { (relevant to PICO question): }\end{array}$ & $\begin{array}{l}\text { - Suture closure of the median sternotomy was significantly } \\
\text { faster than wire closure ( } 6.7 \pm 1.8 \text { minutes versus } 9.1 \pm 1.9 \\
\text { minutes) } \\
\text { - There was no significant difference in post-operative pain } \\
\text { between the two closure groups } \\
\text { - Wound complications were observed in both treatment groups, } \\
\text { including skin dehiscence, incisional drainage and seroma } \\
\text { formation } \\
\text { - There was no significant difference in complication rates } \\
\text { - } \text { - All dogs had stable sternal fixations at day } 7 \\
\text { - All dogs in the wire group had stable sternal fixations at day } 28 \\
\text { - } 3 / 7 \text { dogs in the suture group had unstable sterna at day } 28 \\
\text { - Radiographically, none of the sterna showed complete osseous } \\
\text { - healing at day } 28 \text {. } \\
\text { Radiographically, wire closure resulted in a significantly smaller } \\
\text { fracture gap than suture closure at day } 28 \\
\text { - Histologically, osteochondral/chondral bridging seen in the wire } \\
\text { group ( } 3 \text { sterna) and only fibrous tissue and inflammation seen } \\
\text { in the suture group (3 sterna) at day } 28\end{array}$ \\
\hline
\end{tabular}




\begin{tabular}{|c|c|}
\hline Limitations: & $\begin{array}{l}\text { - Small sample sizes - post-hoc power calculations were } \\
\text { performed for pain and haemodynamic variables and the } \\
\text { authors concluded that the sample sizes were sufficiently large; } \\
\text { however no power calculations were performed for assessment } \\
\text { of sternal stability or bone healing. } \\
\text { - Pain assessment is subjective and was only assessed for the first } \\
24 \text { hours post-operatively } \\
\text { - Not all sterna are accounted for in reported radiographic and } \\
\text { histopathological findings } \\
\text { - Short duration of study ( } 28 \text { days) with no long-term follow-up, } \\
\text { does not allow assessment of complete sternal healing }\end{array}$ \\
\hline
\end{tabular}

\begin{tabular}{|c|c|}
\hline \\
\hline \multicolumn{2}{|r|}{$\begin{array}{l}\text { Canine cadaveric sterna from skeletally mature dogs, weighing } 14.6 \mathrm{~kg} \\
\text { to } 36.8 \mathrm{~kg} \text { and euthanised for reasons unrelated to the study. }\end{array}$} \\
\hline Sample size: & 14 \\
\hline Intervention details: & $\begin{array}{l}\text { For each cadaveric sternum, a median sternotomy was performed using } \\
\text { an oscillating saw. The sterna were halved from the second to the } \\
\text { eighth sternebrae, leaving the manubrium intact. There was no specific } \\
\text { mention as to whether the xiphoid process was cut or not. } \\
\text { Each sternum was randomly assigned to one of the two following } \\
\text { sternotomy closure method groups: } \\
\text { 1) Closure using } 20 \mathrm{G} \text { orthopaedic stainless-steel wire (SSW) in a } \\
\text { figure of } 8 \text { pattern, leaving the wire unbent (7 dogs) } \\
\text { 2) Closure using } 80 \mathrm{lb} \text { monofilament nylon leader (MNL) sutures in } \\
\text { a figure of } 8 \text { pattern, secured with a crimp ( } 7 \text { dogs) } \\
\text { Following sternotomy closure, the sterna were loaded in a mechanical } \\
\text { testing machine and underwent constant axial displacement. Load and } \\
\text { displacement were recorded continuously until failure. Mechanical } \\
\text { testing of each sternum was recorded with a digital video camera and } \\
\text { radiographs were obtained before and after testing to determine the } \\
\text { mode of failure. }\end{array}$ \\
\hline Study design: & Ex-vivo randomised controlled trial \\
\hline Outcome studied: & $\begin{array}{l}\text { - Load at yield } \\
\text { - Maximum load } \\
\text { - Stiffness } \\
\text { - Displacement } \\
\text { - Mode of failure }\end{array}$ \\
\hline $\begin{array}{l}\text { Main findings: } \\
\text { (relevant to PICO question): }\end{array}$ & $\begin{array}{l}\text { There was no significant difference for load at yield, maximum } \\
\text { load at failure, stiffness or mean displacement for SSW and } \\
\text { MNL closure. } \\
\text { - Mode of failure for SSW constructs was fracture of the sterno- } \\
\text { costal junction }(5 / 6) \text { and fracture of the costal cartilage }(1 / 6) \text {. } \\
\text { - Mode of failure for MNL constructs was pulling of the suture }\end{array}$ \\
\hline
\end{tabular}




\begin{tabular}{|c|c|}
\hline & $\begin{array}{l}\text { through the crimp (4/6) and fracture of the sterno-costal } \\
\text { junction }(2 / 6) \text {. }\end{array}$ \\
\hline Limitations: & $\begin{array}{l}\text { - Ex vivo experimental study - may not reflect in vivo conditions } \\
\text { - Sterna subjected to abnormal/non-physiological forces } \\
\text { - Provides information on mechanical properties of } \\
\text { sutures/wires only, unable to draw conclusions regarding post- } \\
\text { operative complications and sternal healing } \\
\text { - Two constructs eliminated from final results } \\
\text { - Small sample size - is the lack of significant difference between } \\
\text { closure methods is true or Type II error (incorrectly accepting } \\
\text { the null hypothesis). No post-hoc power calculations } \\
\text { performed. }\end{array}$ \\
\hline
\end{tabular}

\begin{tabular}{|c|c|}
\hline \\
\hline & Population: \\
\hline Sample size: & 12 \\
\hline Intervention details: & $\begin{array}{l}\text { For each cadaveric sternum, a median sternotomy was performed using } \\
\text { a sagittal saw, cutting from the second sternebra and through the } \\
\text { xiphoid whilst leaving the manubrium intact. Each sternum was } \\
\text { randomly assigned to one of the two following sternotomy closure } \\
\text { groups, with six sterna in each group: } \\
\text { 1) Closure using four metric polydioxanone (PDS) sutures in a } \\
\text { figure of } 8 \text { pattern, secured with a sliding knot and a total of } \\
\text { five throws. } \\
\text { 2) Closure using } 20 \text { G stainless-steel wire (SSW) in a figure of } 8 \\
\text { pattern, leaving the wire unbent. } \\
\text { Following sternotomy closure, the specimens were loaded into a } \\
\text { mechanical testing machine and tested under displacement control } \\
\text { mode, pulling them apart at a constant rate until failure. Radiographs } \\
\text { were obtained before and after testing to determine the mode of } \\
\text { failure. }\end{array}$ \\
\hline Study design: & \\
\hline Outcome studied: & $\begin{array}{l}\text { - Displacement at different loads } \\
\text { - Stiffness } \\
\text { - Mode of failure - failure was defined as a fracture of sternebrae } \\
\text { - } \text { or sternocostal junction, or rupture of wire or suture } \\
\text { - Radiographic findings }\end{array}$ \\
\hline $\begin{array}{l}\text { Main findings: } \\
\text { (relevant to PICO question): }\end{array}$ & $\begin{array}{l}\text { - There was no significant difference in displacement at loads up } \\
\text { to } 400 N \text { or sternal stiffness between the PDS and SSW groups } \\
\text { - The load at failure for the SSW group was significantly higher } \\
\text { than for PDS group } \\
\text { - Mode of failure for the SSW group was fracture of the sterno- } \\
\text { costal junctions (6/6) }\end{array}$ \\
\hline
\end{tabular}




\begin{tabular}{|c|c|}
\hline & $\begin{array}{l}\text { - Mode of failure for the PDS group was suture failure }(5 / 6) \text { and } \\
\text { manubrium fracture }(1 / 6) \\
\text { - Radiographic analysis of SSW specimens showed no evidence of } \\
\text { implant failure }\end{array}$ \\
\hline Limitations: & $\begin{array}{l}\text { - Ex vivo experimental study } \\
\text { - Abnormal forces - only single distractive forces until failure } \\
\text { does not replicate in vivo conditions } \\
\text { Only provides information on mechanical properties of } \\
\text { sutures/wires, unable to draw conclusions regarding post- } \\
\text { operative complications and sternal healing } \\
\text { - Small sample sizes - a power analysis was performed for a } \\
\text { specific setting ( } 2 \text {-mm gap for a load of } 125 \mathrm{~N} \text { ) and it was } \\
\text { concluded that the sample size was ample to show clinical } \\
\text { differences. }\end{array}$ \\
\hline
\end{tabular}

\begin{tabular}{|c|c|}
\hline \multicolumn{2}{|l|}{ Bright (1983) } \\
\hline Population: & Dogs weighing $20 \mathrm{~kg}$ to $30 \mathrm{~kg}$ \\
\hline Sample size: & 9 \\
\hline Intervention details: & $\begin{array}{l}\text { A median sternotomy was performed for all nine dogs. All sterna were } \\
\text { closed with parasternal and transsternal orthopaedic wires. For the first } \\
\text { five dogs non-swaged wire was used. Swaged wire was used for the } \\
\text { final four dogs. The dogs were assessed daily for } 30 \text { days post- } \\
\text { operatively and were then euthanised. }\end{array}$ \\
\hline Study design: & Descriptive/non-comparative case series \\
\hline Outcome studied: & $\begin{array}{l}\text { Daily records of pain, pleural drainage, gross wound } \\
\text { characteristics and pyrexia were taken for } 30 \text { days. } \\
\text { - Post-mortem assessment of wound healing was made at day } 30 \\
\text { and included: } \\
\text { - Gross assessment of wound healing } \\
\text { - Manual assessment of sternal stability } \\
\text { - } \quad \text { Radiographic evidence of healing }\end{array}$ \\
\hline $\begin{array}{l}\text { Main findings: } \\
\text { (relevant to PICO question): }\end{array}$ & $\begin{array}{l}\text { - Post-operative pain was noted in } 4 / 9 \text { dogs, with one dog } \\
\text { - } \text { - Wound complications were recorded in } 5 / 9 \text { dogs }(56 \%) \\
\text { - Fewer complications noted following change from use of non- } \\
\text { - swaged to swaged wire. } \\
\text { - } \text { - Radl dogs had a clinically stable sternum at } 30 \text { days } \\
\text { - Displacement in } 8 / 9 \text { dogs } \\
\text { - } \text { - Po signs of osseous healing in } 6 / 9 \text { dogs } \\
\text { - Complete osseous bridging in one dog } \\
\text { - Radiographs showed the following complications: } \\
\text { - cranio-caudal shift of sternebrae } \\
\text { - boney lysis } \\
\text { - reabsorption of sternebrae }\end{array}$ \\
\hline
\end{tabular}




\begin{tabular}{|l|l|l|}
\hline & $\begin{array}{l}\text { - } \text { wire breakage } \\
\text { The authors concluded that fibrous union provided sufficient } \\
\text { stability to the sternum }\end{array}$ \\
& $\begin{array}{l}\text { Para-sternal wiring technique shown to be effective in } \\
\text { preventing cortical destruction in human studies not supported } \\
\text { by the findings of this paper. }\end{array}$ \\
\hline Limitations: & $\begin{array}{l}\text { Small sample sizes } \\
\text { - }\end{array}$ \\
& $\begin{array}{l}\text { No control groups - unable to draw comparisons with other } \\
\text { methods of wire or suture closure. } \\
\text { More than one surgeon performed the surgeries - unable to } \\
\text { state whether reduced complication rate following change in } \\
\text { surgical technique was the result of use of swaged wire or } \\
\text { improved technique/experience/surgeon variability. }\end{array}$ \\
\hline \begin{tabular}{l} 
Pain assessment subjective \\
\hline
\end{tabular} &
\end{tabular}

\begin{tabular}{|c|c|}
\hline \multicolumn{2}{|l|}{ Davis (2006) } \\
\hline Population: & $\begin{array}{l}\text { Sternal segments from dogs weighing } 22.8 \mathrm{~kg} \text { to } 43.3 \mathrm{~kg} \text {, euthanised for } \\
\text { reasons unrelated to the study. }\end{array}$ \\
\hline Sample size: & 40 \\
\hline Intervention details: & $\begin{array}{l}\text { The sternal segments were clamped into a custom-made platform and a } \\
\text { complete median sternotomy was performed using a sagittal saw. All } \\
\text { sternal segments were closed using } 18 \mathrm{G} \text { orthopaedic wire and were } \\
\text { randomly assigned to one of the following five sternotomy closure } \\
\text { groups with a total of eight specimens per group: } \\
\text { 1) Two single twist cerclage centered on the sternebrae } \\
\text { 2) Single twist figure of } 8 \text { pattern centered on the sternal } \\
\text { synchondrosis } \\
\text { 3) Double twist figure of } 8 \text { pattern centered on the sternal } \\
\text { synchondrosis } \\
\text { 4) Two double looped cerclage centered on the sternebrae } \\
\text { 5) Double loop cerclage centered over the sternal synchondrosis } \\
\text { Each segment was radiographed and then loaded into a custom-made } \\
\text { jig. Each specimen was loaded to failure in tension and the process was } \\
\text { recorded with a digital video camera. Displacement at each load was } \\
\text { measured. The specimens were then radiographed to determine the } \\
\text { mode of failure. }\end{array}$ \\
\hline Study design: & Ex-vivo randomised controlled trial \\
\hline Outcome studied: & $\begin{array}{ll}\text { - } & \text { Displacement } \\
\text { - } & \text { Load at failure } \\
\text { - } & \text { Radiographic findings }\end{array}$ \\
\hline $\begin{array}{l}\text { Main findings: } \\
\text { (relevant to PICO question): }\end{array}$ & $\begin{array}{l}\text { - There were no significant differences in displacement between } \\
\text { fixation methods for loads } \leq 125 \mathrm{~N}\end{array}$ \\
\hline
\end{tabular}




\begin{tabular}{|c|c|}
\hline & $\begin{array}{l}\text { - Sternal wiring techniques centred on the sternal synchondroses } \\
\text { (groups 2, } 3 \text { and } 5) \text { had the least displacement at higher loads } \\
(150,175, \text { and } 200 \mathrm{~N}) \text { when compared with techniques centered } \\
\text { on the sternebrae. } \\
\text { - Both figure of } 8 \text { patterns (groups } 2 \text { and } 3 \text { ) had the least } \\
\text { displacement at higher loads }(150,175 \text {, and } 200 \mathrm{~N}) \\
\text { - Sternal body fracture was the most common method of failure } \\
\text { for all groups. }\end{array}$ \\
\hline Limitations: & $\begin{array}{l}\text { - Ex-vivo experimental study } \\
\text { - Sternal segments consisted of two sternebrae and therefore } \\
\text { - } \text { have different mechanical properties to an entire sternum } \\
\text { - } \quad \text { single pull to failure - different to in vivo conditions } \\
\text { - } \quad \text { Provides no information on post-operative outcome } \\
\text { - Nomparison with suture closure methods }\end{array}$ \\
\hline
\end{tabular}

\section{Appraisal, application and reflection}

Five articles were reviewed, four of which were randomised controlled trials (including two experimental exvivo studies), with the remaining article being a non-comparative case series.

The clinical bottom line can be summarised as:

"The literature search revealed no clinical studies on large breed dogs comparing the clinical outcomes following either orthopaedic wire or suture sternotomy closure methods. Post-mortem studies on large breed dogs suggest that sutures are as suitable as orthopaedic wires for sternal closure with regards to their biomechanical properties. There is insufficient clinical evidence to make a recommendation that sutures be used in large breeds of dog."

Median sternotomy in dogs is associated with a high rate of post-operative complications. Common complications include; seroma formation, skin dehiscence, discharging sinus tracts, osteomyelitis and postoperative pain. There are several different sternotomy closure techniques discussed in the human and veterinary literature, however there are few studies that directly compare the use of suture versus wire for median sternotomy closure in large breed dogs.

Of the articles reviewed, Pelsue et al (2002) directly compares wire and suture median sternotomy closure in large breed dogs in a randomised controlled trial. Interestingly, no significant difference in complication rates was found between the two closure methods over a 28 day period. In addition, there was no significant difference in post-operative pain in the first 24 hours following surgery between the wire and suture group. Randomised controlled trials provide a good level of evidence, however the small sample sizes used in this study must be considered when interpreting the significance of these results. Post-hoc power calculations were performed for pain and haemodynamic variables, for which the authors concluded that the sample sizes were sufficiently large to discount Type II error. However, no power calculations were performed for assessment of sternal stability or bone healing, for which the sample sizes were the smallest.

Pelsue et al (2002), conclude that wire sternotomy closure is superior to suture sternotomy closure and recommend its use in large breed dogs. However, no direct correlation between the findings of this study and clinical outcome has been drawn. Furthermore, the conclusions are based on results that indicate that sterna closed with wires had a significantly smaller fracture gap and histological evidence of superior sternal healing when compared with sterna closed using sutures. However, study duration is a limitation of this study, as at 28 days none of the sterna showed complete osseous healing, indicating that the study duration was not long enough to assess complete sternal healing. This result is echoed by a non-comparative case series by Bright et al (1983), in which nine dogs underwent median sternotomy with wire closure; eight of which had either no radiographic signs of osseous healing or only partial healing at 30 days post-operatively. It is therefore 
difficult to draw meaningful conclusions on sternal healing from data collected in such a short time frame. It also appears from our search that there are no available studies that correlate the apparent weakness of sternotomy suture closure in large dogs with clinical outcome.

Two experimental ex-vivo studies compare the mechanical properties of suture versus wire closure of median sternotomy (Gines et al, 2011 \& McCready et al, 2015). Both found sutures and wires to be mechanically comparable when exposed to forces deemed as physiological (<400N). Gines et al (2011) demonstrated that wire has a superior loading force to failure when compared with sutures. However, neither of these studies provide information on post-operative outcome and therefore the clinical significance of these ex-vivo studies remains undetermined.

In summary, it is evident that there is a requirement for more large-scale clinical studies directly comparing the use of wires and sutures for median sternotomy closure in large breed dogs. Retrospective studies reviewing the clinical outcome of large breed dogs undergoing suture sternotomy closure would also provide useful information and enable more informed clinical decision making in the future.

\section{Methodology Section}

\section{Search Strategy}

Databases searched and dates covered:

CAB Abstracts on Ovid 1973 to 2017 Week 20

Medline on Ovid 1946 to May 2017

Search terms: Dogs/ OR (dog* or canine*).mp

AND

Sternotomy/ OR sternotom*.mp

AND

wire*.mp OR Sutures/ OR Polydioxanone/ OR Nylons/

OR (suture* or polydioxanone or nylon).mp

Dates searches performed:

$31 / 05 / 2017$

\section{Exclusion / Inclusion Criteria}

Exclusion: Case reports, articles not relevant to the PICO question and duplicated articles

Inclusion: All accessible articles relevant to the PICO question

\begin{tabular}{|l|c|c|c|c|c|c|}
\hline \multicolumn{2}{|l|}{ Search Outcome } \\
\hline Database & $\begin{array}{c}\text { Number of } \\
\text { results }\end{array}$ & $\begin{array}{c}\text { Excluded - } \\
\text { case report }\end{array}$ & $\begin{array}{c}\text { Excluded - not } \\
\text { relevant to } \\
\text { PICO question }\end{array}$ & $\begin{array}{c}\text { Excluded - } \\
\text { not available }\end{array}$ & $\begin{array}{c}\text { Excluded - } \\
\text { duplicated }\end{array}$ & $\begin{array}{c}\text { Total } \\
\text { relevant } \\
\text { papers }\end{array}$ \\
\hline $\begin{array}{l}\text { CAB } \\
\text { Abstracts }\end{array}$ & 12 & 1 & 5 & 1 & 0 & 5 \\
\hline MEDLINE & 24 & 2 & 18 & 0 & 4 & 0 \\
\hline Total relevant papers when duplicates removed & & & & 5 \\
\hline
\end{tabular}




\section{CONFLICT OF INTEREST}

The authors declare no conflict of interest.

\section{REFERENCES}

1. Bright, R., McIntosh Bright, J., Richardson, D. et al (1983) Clinical and Radiographic Evaluation of a Median Sternotomy Technique in the dog. Journal of Veterinary Surgery. 12 (1) pp.13-19. DOI: http://dx.doi.org/10.1111/j.1532-950X.1983.tb00695.x

2. Davis, K., Roe, S., Mathews, K. et al. (2006) Median Sternotomy Closure in Dogs: A mechanical Comparison of Technique Stability. Journal of Veterinary Surgery. 35 pp. 271-277. DOI: http://dx.doi.org/10.1111/j.1532-950X.2006.00143.x

3. Gines, J., Friend, E., Vives, M. et al. (2011) Mechanical comparison of median sternotomy closure in dogs using polydioxanone and wire sutures. Journal of Small Animal Practice. 52 pp. 582-586. DOI: http://dx.doi.org/10.1111/j.1748-5827.2011.01106.x

4. McCready, D., Bell, J., Ness, M. et al. (2015) Mechanical comparison of monofilament nylon leader and orthopaedic wire for median sternotomy closure. Journal of Small Animal Practice. 56 (8) pp. 510-515. DOI: http://dx.doi.org/10.1111/isap.12378

5. Pelsue, D., Monnet, E., Gaynor, J. et al. (2002) Closure of Median Sternotomy in Dogs: Suture Versus Wire. Journal of the American Animal Hospital Association. 38 pp. 569-576. DOI: http://dx.doi.org/10.5326/0380569 


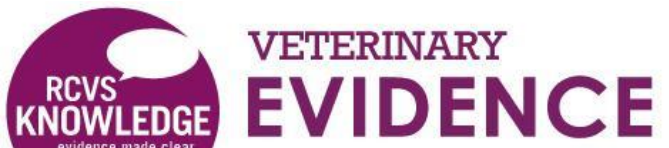 \\ online}

\section{Intellectual Property Rights}

Authors of Knowledge Summaries submitted to RCVS Knowledge for publication will retain copyright in their work, and will be required to grant to RCVS Knowledge a non-exclusive license of the rights of copyright in the materials including but not limited to the right to publish, re-publish, transmit, sell, distribute and otherwise use the materials in all languages and all media throughout the world, and to license or permit others to do so.

\section{Disclaimer}

Knowledge Summaries are a peer-reviewed article type which aims to answer a clinical question based on the best available current evidence. It does not override the responsibility

of the practitioner. Informed decisions should be made by considering such factors as individual clinical expertise and judgement along with patient's circumstances and owners' values. Knowledge Summaries are a resource to help inform and any opinions expressed within the Knowledge Summaries are the author's own and do not necessarily reflect the view of the RCVS Knowledge.

Veterinary Evidence and EBVM Network are RCVS Knowledge initiatives. For more information please contact us at editor@veterinaryevidence.org

RCVS Knowledge is the independent charity associated with the Royal College of Veterinary Surgeons (RCVS). Our ambition is to become a global intermediary for evidence based veterinary knowledge by providing access to information that is of immediate value to practicing veterinary professionals and directly contributes to evidence based clinical decision-making.

www.veterinaryevidence.org

RCVS Knowledge is a registered Charity No. 230886. Registered as a Company limited by guarantee in England and Wales No. 598443.

Registered Office:

Belgravia House

62-64 Horseferry Road

London SW1P 2AF 